Vol. 10. No.1. Tahun 2022

\title{
PENDIDIKAN KARAKTER DI PERGURUAN TINGGI BERPENGARUH TERHADAP DEKANDENSI MORAL DI KALANGAN MAHASISWA
}

\author{
Endang Kartini, ${ }^{1)}$ Lalu Mimbar, ${ }^{2)}$ Izrawati, ${ }^{3)}$
}

1)2) STIE AMM Mataram, ${ }^{3)}$ MTs.Negeri 1 Lombok Barat

endangkartini979@gmail.com, mamiqmimbar@gmail.com, zrawati12@gamil.com

\begin{abstract}
Abstrak
Penelitian ini bertujuan untuk mengetahui pengaruh Adab/perilaku terhadap sesama dalam keseharian, Adil, Amanah, Arif dan Bijaksana, Bertanggungjawab, Daya juang (tangguh), Disiplin, Ikhlas, Inovatif, Jujur , Kepedulian terhadap masyarakat dan lingkungan, dan Kepekaan berpengaruh terhadap dekandisi nilai moral dikalangan mahasiswa.Jenis penelitian adalah asosiatif artinya hubungan antar independen dan dependen.Populasi penelitian adalah Mahasiswa STIEAMM Mataram Program Studi Akuntansi SMT V dan Program Studi Manajemen SMT VII sebanyak 176 Mahasiswa. Sampel Penelitian sebanyak 64 responden.

Hasil Penelitian menunjukkan bahwa Nilai konstanta $(\alpha)$ sebesar 2.861 artinya dekandensi moral dikalangan mahasiswa sebesar 2.861 satuan dengan asumsi variabel karakter adab/perilaku, karakter adil, karakter amanah, tanggung jawab, daya juang, disiplin, ikhlas, inovatif, jujur,kepedulian, dan kepekaan dalam keadaan konstan atau tetap, Dilihat dari sebelas (11) variable rata-rata mempunyai probabilitas signifikansi yang lebih besar dari (>0.05), hal ini membuktikan bahwa terjadi hubungan yang serah variable independen dengan dependen. Secara individual pendidikan karakter masing-masing mempunyai pengaruh dan signifikan terhadap dekandensi moral mahasiswa. Sedangkan secara simultan atau bersama-sama dimana nilai $\mathrm{F}$ hitung sebesar 37.204 dan signifikansi 0,000. dikatakan bahwa $\mathrm{F}$ hitung lebih besar dari $\mathrm{F}$ tabel (37.204 > 2.39) Hal ini dikatkan bahwa terdapat pengaruh yang signifikan pendidikan karakter terhadap dekandensi moral dikalangan mahasiswa. Kemudian apabila dikaitkan dengan kuat atau lemahnya hubungan variable independen dan dependen maka sebagaimana yang dihasilkan koefisien determinasi dengan nilai $\mathrm{R}$ sebesar 0.860 berarti hubungan Korelasi cukup kuat Adjusted $R$ Square (R2) $=0.722$ : Dekandensi moral dikalangan Mahasiswa dapat dijelaskan melalui sebelas (11) variable hanya sebesar $72.2 \%$. Sedangkan $27.8 \%(100 \%-72.2 \%)$ dapat dijelaskan melalui variebl-variabel lain yang tidak dimasukkan dalam penelitian ini.
\end{abstract}

Kata Kunci : Pendikan Karakter, Perguruan Tinggi, Dekandensi Moral Di Kalangan Mahasiswa

\section{ABSTRACT}

This study aims to determine the influence of Adab/behavior towards others in daily life, Fair, Trustworthy, Wise and Wise, Responsible, Strength (tough), Discipline, Sincerity, Innovative, Honest, Concern for society and the environment, and Sensitivity affect the decandition of values. morale among students. The type of research is associative, meaning the relationship between independent and dependent. The research population is students of STIEAMM Mataram Accounting Study Program SMT V and Management Study Program SMT VII as many as 176 students. The research sample was 64 respondents.

The results showed that the constant value $(\alpha)$ was 2.861, meaning that moral decandence among students was 2.861 units with the assumption that the variables were character/behavior, fair character, trustworthy character, responsibility, fighting power, discipline, sincerity, innovativeness, honesty, caring, and sensitivity in a constant or constant state, Judging from eleven (11) the average variable has a significance probability greater than (>0.05), this proves that there is a direct relationship between the independent variable and the dependent variable. Individually, each character education has a significant and significant impact on students' moral decandence. Meanwhile, simultaneously or together where the calculated $F$ value is 37,204 and the significance is 0.000. it is said that the calculated $F$ is greater than the $F$ table $(37,204>2.39)$ This means that there is a significant effect of character education on moral decandence among students. Then, if it is associated with a strong or weak relationship between the independent and dependent variables, as the resulting coefficient of determination with an $R$ value of 0.860 means the correlation is quite strong Adjusted $R$ Square $(R 2)=0.722:$ Moral decadence among students can be explained through eleven (11) variables only by $72.2 \%$. While $27.8 \%(100 \%-72.2 \%)$ can be explained through other variables not included in this study.

Keywords: Character Education, Higher Education, Moral DecandencyAmong Students 


\section{PENDAHULUAN}

Pendidikan merupakan salah satu pilar yang ikut menopang berdirinya sebuah peradaban yang disebut dengan Bangsa.Eksistensi suatu bangsa sangat ditentukan oleh karakter yang dimilikinya. Bangsa yang memiliki karakter kuat dapat menjadi bangsa yang bermartabat dan disegani oleh bangsa lain di seluruh dunia. Menjadi sebuah bangsa yang berkarakter sudah menjadi tujuan bangsa Indonesia. Hal ini sesuai dengan Fungsi Pendidikan Nasional yang tertuang dalam UU No 20 Tahun 2003 tentang Sistem Pendidikan Nasional yaitu Pendidikan nasional berfungsi mengembangkan kemampuan dan membentuk watak serta peradaban bangsa yang bermartabat dalam rangka mencerdaskan kehidupan bangsa, bertujuan untuk berkembangnya potensi peserta didik agar menjadi manusia yang beriman dan bertakwa kepada Tuhan Yang Maha Esa, berakhlak mulia, sehat, berilmu, cakap, kreatif, mandiri, dan menjadi warga negara yang demokratis serta bertanggung jawab.

Pendidikan karakter sebenarnya bukan hal yang baru bagi masyarakat Indonesia.Bahkan sejak awal kemerdekaan, masa orde lama, masa orde baru, dan kini orde reformasi telah banyak langkah-langkah yang sudah dilakukan dalam kerangka pendidikan karakter dengan nama dan bentuk yang berbeda-beda. Dalam UU tentang pendidikan nasional yang pertama kali, ialah UU 1946 yang berlaku tahun 1947 hingga UU Sisdiknas Nomor 20 tahun 2003 yang terakhir pendidikan karakter telah ada, namun belum menjadi fokus utama pendidikan. Pendidikan akhlak (karakter) masih digabung dalam mata pelajaran agama dan diserahkan sepenuhnya pada guru agama. Karena pelaksanaan pendidikan karakter hanya diserahkan kepada guru agama saja. Maka wajar hingga saat ini pendidikan karakter belum menunjukkan hasil yang optimal. Hal ini terbukti dari fenomena sosial yang menunjukkan perilaku yang tidak berkarakter,misalnya sering terjadinya tawuran antar pelajar, adanya pergaulan bebas, dan adanya kesenjangan sosialekonomi-politik di masyarakat, kerusakan lingkungan yang terjadi di seluruh pelosok negeri, masih terjadinya ketidakadilan hukum, kekerasan dan kerusuhan, dan korupsi yang mewabah dan merambah pada semua sector kehidupan masyarakat, tindakan anarkis, serta konflik sosial.

Namun kenyataanya sampai saat ini banyak masalah-maslah yang menodai dunia pendidikan kita. Hal ini bisa dilihat dari berbagai peristiwa-peristiwa tawuran antar pelajar, demonstrasi yang anarkhis yang juga banyak dilakukan oleh mahasiswa. Mereka bersugesti dengan tindakkan tawuran maupun kekerasan yang mereka lakukan dapat menunjukkan kekuasaan dan kekuatan mereka. Mereka ingin dianggap sebagai generasi yang kuat tetapi cara yang mereka tempuh salah. Mereka dapat dengan mudah diprovokasi apalagi dengan mengkonsumsi narkoba membuat mereka hilang kesadaran dan akal sehat, sehingga dapat mengakibatkan tindakan yang diluar kontrol akal mereka. Sejumlah tindakan pelajar dan mahasiswaq yang merupakan generasi muda bangsa yang kurang baik itu menunjukkan indikasi lunturnya nilai-nilai karakter bangsa

$$
\text { Pelajar maupun mahasiswa }
$$
merupaka generasi muda yang dididik untuk menjadi insan-insan inteluktual untuk dapat mendudukung pembangunan bangsa melalui pendidikan. Hal ini berkaitan dengan makna pendidikan yang merupakan suatu proses yang terjadi secara terus-menerus yang bertujuan untuk mengubah jati diri seseorang yang lebih maju dan berkembang dalam ilmu pengetahuan. Dengan adanya perkembangan zaman, dunia pendidikan terus berubah secara signifikan sehingga banyak merubah pola pikir banyak orang, dari pola pikir yang masih sederhana menjadi lebih modern. Dengan melalui pendidikan formal diharapkan akan lebih terarah dalam memperoleh nilai-nilai kebenaran yang berlaku di dalam normanorma kehidupan disamping mendapatkan ilmu pengetahuan yang sesuai dengan bidangnya masing-masing.

Dekandensi moral di kalangan Mahasiswa di pengaruhi oleh pengembangan kemampuan dan membentuk watak serta 
peradaban bangsa yang bermartabat dalam rangka mencerdaskan kehidupan bangsa, bertujuan untuk berkembangnya potensi sebagai peserta didik agar menjadi manusia yang beriman dan bertakwa kepada Tuhan Yang Maha Esa, berakhlak mulia, sehat, berilmu, cakap, kreatif, mandiri, dan menjadi warga negara yang demokratis serta bertanggung jawab, namun nampaknya upaya pendidikan yang dilakukan oleh lembaga pendidikan dan institusi pembina lain belum sepenuhnya mengarahkan dan mencurahkan perhatian secara komprehensif pada upaya pencapaian tujuan pendidikan nasional. Oleh karena itu secara umum dekandensi moral dikalangan generasi muda atau mahasiswa sangat dipengaruhi oleh pembentukan dan pengembangan potensi, perbaikan dan penguatan, serta penyaringan. Di lingkungan perguruan tinggi mahasiswa merupakan elemen yang paling peka merespon problematika bangsa sebagai promotor "pioople power" yang menyangkut kepentingan masyarakat umum. Mahasiswa sebagai agen perubahan dimaksudkan bahwa dalam mengadakan sebuah perubahan yang holistik dan sistematik demi kemaslahatan bersama, maka mahasiswa dituntut memiliki kapasitas dan kapabilitas untuk itu. Pendidikan yang hanya berbasis pada pengembangan intelektual tanpa pengembangan nilai-nila spiritual dan keseimbangan emosional, merupakan metode pendidikan yang perlu dikoreksi. Sebab, intelegensia tinggi tanpa diimbangi dengan nilai-nilai spiritual dan keseimbangan emosional, tidak akan menghasilkan kecerdasan sosial yang diharapkan.

Perkembangan ilmu pengetahuan dan teknologi saat ini mengharuskan Sekolah Tinggi Ilmu Ekonomi AMM Mataram sebagai lembaga pendidikan melakukan upaya-upaya sistematis, terencana, terukur dan berkelanjutan untuk melejitkan potensi mahasiswa agar menjadi alumni yang dapat menjadi inovator, mandiri, pionir, pencipta (creator), pemimpin, menguasai Informasi dan Teknologi (IT), cakap dalam berkomunikasi lisan dan tulisan, profesional, memiliki etika, memiliki tanggung jawab sosial dan berjiwa wirausaha (enterpreneur) dengan kemampuan berpikir analitis, kritis dan logis. Sekolah Tinggi Ilmu Ekonomi sebagai sebuah perguruan tinggi yang memiliki inovatif, mandiri, dalam bidang pendidikan, penelitian, dan pengabdian kepada masyarakat, perlu bersinergi dengan rencana strategis yang telah dirumuskan. Disamping itu, Sekolah Tinggi Ilmu Ekonomi juga perlu menerapkan strategi yang handal untuk peningkatan mutu, relevansi, akses, daya saing dan tata kelola dalam era revolusi industri dan dapat berkontribusi dalam revolusi peradaban (society) 5.0 (Fukuyama, 2018).

Karakter-karakter mahasiswa yang diturunkan dari nilai-nilai prioritas Sekolah Tinggi Ilmu Ekononmi AMM Mataram yaitu: Adab/perilaku terhadap sesama dalam keseharian, Adil, Amanah, Arif dan Bijaksana, Bertanggungjawab, Daya juang (tangguh), Disiplin, Ikhlas, Inovatif , Jujur , Kepedulian terhadap masyarakat dan lingkungan, dan Kepekaan. Strategi perumusan masalah dapat dilakukan melalui melihat langsung suasana interaksi belajar dan pembelajaran yang sengaja dirancang untuk mencapai tujuan pembentukan karakter dengan menerapkan kegiatan yang terstruktur.Fokus pada permasalahan adalah apakah Adab/perilaku terhadap sesama dalam keseharian, Adil, Amanah, Arif dan Bijaksana, Bertanggungjawab, Daya juang (tangguh), Disiplin, Ikhlas, Inovatif , Jujur , Kepedulian terhadap masyarakat dan lingkungan, dan Kepekaan berpengaruh terhadap dekandisi nilai moral dikalangan mahasiswa? Selajutnya dengan tujuan mengetahui pengaruh Adab/perilaku terhadap sesama dalam keseharian, Adil, Amanah, Arif dan Bijaksana, Bertanggungjawab, Daya juang (tangguh), Disiplin, Ikhlas, Inovatif , Jujur, Kepedulian terhadap masyarakat dan lingkungan, dan Kepekaan berpengaruh terhadap dekandisi nilai moral dikalangan mahasiswa.

\section{TINJAUAN TIORITIS}

Pengertian pendidikan secara umum dapat kita artikan sebagai suatu usaha sadar yang dilakukan oleh individu, kelompok, lembaga dalam rangka menanamkan pengetahuan (kognitif), 
menanamkan nilai-nilai atau sikap (afektif), dan melatih keterampilan (psikomotorik) kepada para peserta didik untuk mempersiapkan masa depannya yang lebih baik/maju.

Menurut Kementerian Pendidikan Nasional (2010: 3) karakter adalah watak, tabiat, akhlak, atau kepribadian seseorang yang terbentuk dari hasil internalisasi berbagai kebajikan (virtues) yang diyakini dan digunakan sebagai landasan untuk cara pandang, berpikir, bersikap, dan bertindak. Terminologi karakter sedikitnya memuat dua hal yaitu values (nilai-nilai) dan kepribadian. Sebagai suatu cerminan dari kepribadian yang utuh, karakter mendasarkan diri pada tata nilai yang dianut masyarakat. Tata nilai yang mendasari pemikiran serta perilaku individu ini ditanamkan dengan proses internalisasi nilai yang sesuai dengan budaya yang dianut oleh masyarakat. Proses internalisasi inilah yang kemudian membentuk karakter seorang individu

\section{Penerapan Pendidikan Karakter Di Kalangan Mahasiswa}

Menurut kamus bahasa Indonesia, mahasiswa adalah orang yang belajar (peserta didik) di perguruan tinggi (Pusat Bahasa Depdiknas, 2008: 895). Sementara itu Flexner dalam Syukri (2009) berpendapat bahwa perguruan tinggi merupakan tempat pencarian ilmu pengetahuan, pemecahan berbagai masalah,tempat mengkritisi karyakarya yang dihasilkan,dan sebagai pusat pelatihan manusia. Jadi, mahasiswa dididik dan dilatih di perguruan tinggi agar menjadi manusia intelektual yang mempunyai daya nalar tinggi, analisa yang luas dan tajam, berilmu tinggi dan berprilaku terpuji.

Arthur dalam Syukri (2009) yaitu pengajaran, penelitian dan aplikasi ilmu pengetahuan, yang secara tersirat membentuk opini bahwa pembentukan karakter bukan tugas perguruan tinggi. Kemudian Schwartz (2000) menyatakan ada beberapa hal yang mengundang kekeliruan terkait penerapan pendidikan karakter dikalangan mahasiswa,yaitu:

1. Karakter seseorang sudah terbemtuk sebelum masuk ke perguruan tinggi dan merupakan tanggung jawab orang tua untuk membentuk karakter anaknya.

2. Perguruan tinggi, khususnya dosen, tidak memiliki kepentingan dengan pembentikan karakter, karena mereka direkrut bukan untuk melakukan hal tersebut.

3. Karakter merupakan istilah yang mengacu pada agama tau ideology konservatif tertentu, sementara itu perguruan tinggi di barat secara umum melepaskan diri dari agama atau idiologi tertentu.

Dari penjelasan diatas dapat disimpulkan bahwa sebenarnya pendidikan karakter di perguruan tinggi dapat melengkap karakter yang sudah terbentuk pada diri mahasiswa yang didapat pada tingkat pendidikan sebelumnya, namun hal tersebut belum berjalan sebagaimana mestinya.

Soetanto (2012) menjabarkan bahwa penerapan pendidikan karakter di perguruan tinggi didasarkan pada lima pilar utama:

1. Tri Darma Perguruan Tinggi

Pendidikan karakter bisa diintegrasikan ke dalam kegiatan pendidikan, penelitian dan pengabdian kepada masyarakat yang berkarakter.

2. Budaya Perguruan Tinggi (kampus)/ Budaya Organisasi

Mahasiswa dituntut untuk dapat membiasakan diri dalam kehidupan keseharian di lingkungan perguruan tinggi.

3. Kegiatan Kemahasiswaan

Pendidikan karakter dapat diciptakan melalui integrasi ke dalam kegiatan kemahasiswaan, antara lain pramuka, olahraga, karya tulis, seni, workshop, dan acara yang melibatkan mahasiswa dalam system kepanitiaannya.

4. Kegiatan Keseharian

Pendidikan karakter dapat dimunculkan dengan penerapan pembiasaan kehidupan keseharian di lingkungan keluarga, asrama, dan masyarakat.

5. Budaya Akademik

Nilai pendidikan karakter secara persfektif terbentuk dengan adanya totalitas budaya akademik. 


\section{Alur Pemikiran}

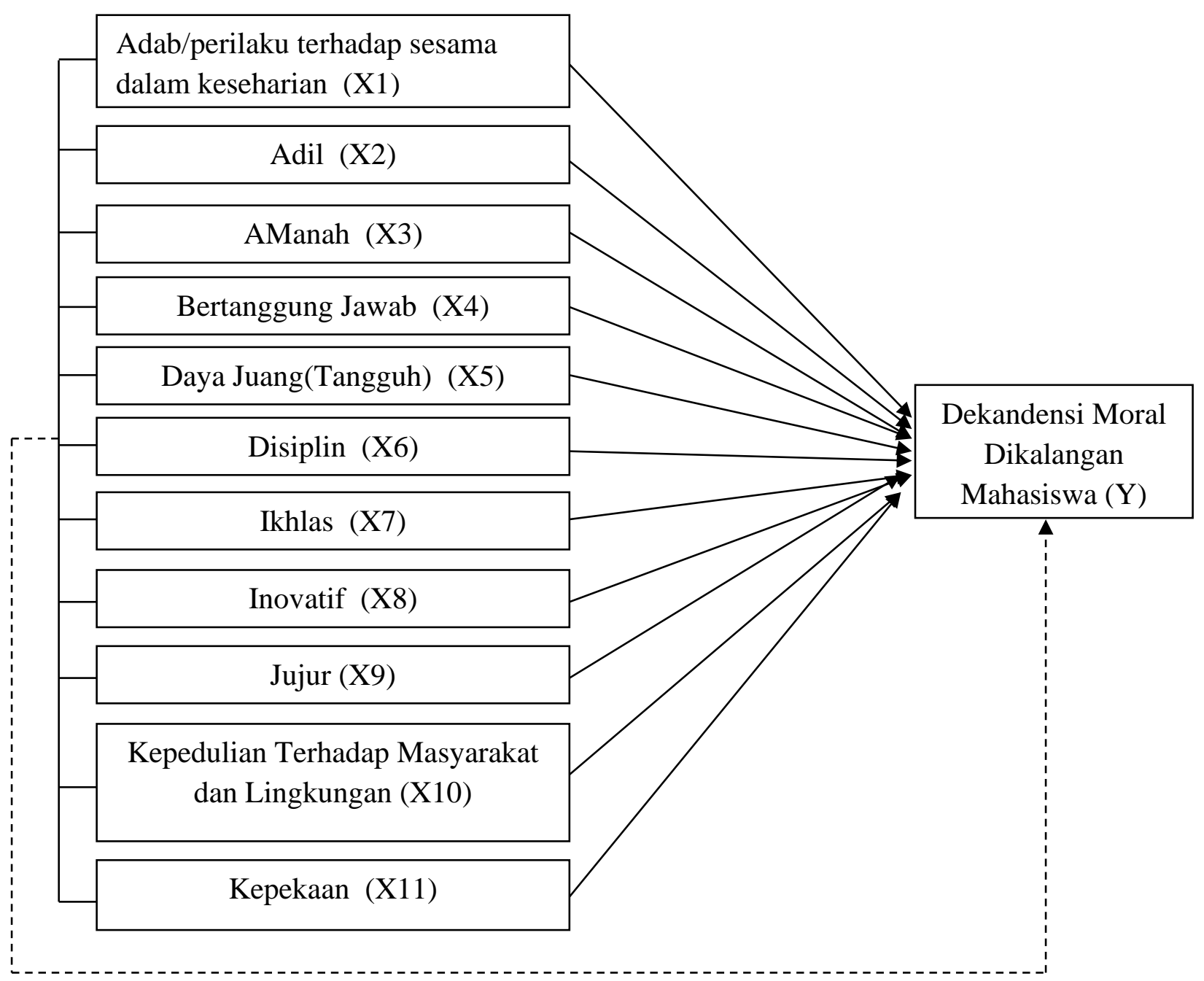

Keterangan:

Gambar Alur Pemikiran

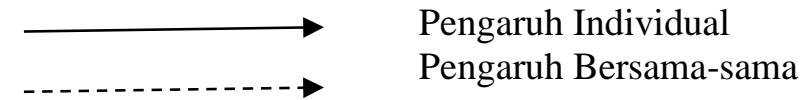




\section{METODE PENELITIAN Jenis penelitian}

Jenis penelitian yang digunakan adalah asosiatif atau sebab akibat (kausal),yaitu untuk mengetahui pengaruh pendidikan karakter terhadap dekandendi moral dikalangan Mahasiswa. Menurut Sugiyono (2006) penelitian asosiatif adalah jenis penelitian yang bertujuan untuk mengetahui pengaruh suatu variabel terhadap variabel lainnya..

\section{Teknik Pengumpulan Data}

\section{Koesioner (questionnaires)}

Kuesioner adalah sejumlah pertanyaan yang digunakan untuk memperoleh informasi dari responden dalam arti laporan tentang pribadinya, atau hal-hal yang ia ketahui. (Suharsimi Arikunto;2010;194). Kuesioner ini di sebar lewat oline, Skala yang dipakai dalam penyusunan kuesioner adalah skala Likert, yaitu skala yang berisi lima tingkatan nilai untuk mewakili pendapat responden, nilai untuk skala tersebut adalah : 1).sangat setuju, diwakili angka 5,2) setuju, diwakili angka 4, 3) netral, diwakili angka 3,4) tidak setuju, diwakili angka 2, dan 5) sangat tidak setuju, diwakili angka 1

\section{Dokumentasi}

Metode dokumentasi yaitu mencari data mengenai ha-hal atau variabel yang berupa catatan, transkip, buku, surat kabar, majalah, prasasti, notulen rapat, legger, agenda dan sebagainya (Suharsimi,2006:231). Data Mahasiswa yang diperoleh dari bagian BAAK dan Jurusan disesuaikan dengan populasi digunakan dalam penelitian ini.

\section{Populasi, Sampel dan Teknik Pengambilan Sampel Populasi}

Populasi adalah keseluruhan subjek penelitian (Arikunto, 2010:173), sedangkan pendapat lain, mengatakan bahwa populasi adalah sebuah kumpulan dari semua kemungkinan orang-orang, benda-benda dan ukuran lain dari objek yang menjadi perhatian (Suharyadi dan Purwanto, 2007:12). Yang menjadi populasi adalah Mahasiswa Prodi Akuntansi SMTV Kls.B, SMT VII Kls A, SMT 7 Kls.B. dan Prodi Manajemen SMT VII Kls. C Semester Ganjil tahun 2021/2022 berjumlah 176 orang, dapat dilihat pada Tabel 3.1 berikut.

\begin{tabular}{clc}
\multicolumn{4}{c}{ Tabel 3.1 Populasi Penelitian } \\
No. & Program Studi / & Jumlah \\
& Kls./SMT & Mahasiswa \\
1 & Akuntansi B / V & 40 \\
2 & Akuntansi A /VII & 46 \\
3 & Akuntansi B / VII/ & 42 \\
4 & Manajemen C /VII & 50 \\
& Jumlah & $\mathbf{1 7 6}$ \\
Sumber Data STIEAMM &
\end{tabular}

\section{Sampel}

Sampel adalah suatu bagian dari populasi tertentu yang menjadi perhatian ((Suharyadi dan Purwanto, 2007:12). Dalam penelitian ini untuk menentukan besaran sample penulis menggunakan rumus Slovin, dikutip dari (Umar, 2008:78).

$$
n=\frac{N}{1+N(e)^{2}}
$$

Dimana:

$\mathrm{n}=$ Ukuran sampel

$\mathrm{N}=$ Ukuran populasi

$\mathrm{e}=$ Persen kelonggaran ketidakpastian karena kesalahan pengambilan sampel yang masih di tolerir, maksimum $10 \%$.

Berdasarkan rumus di atas dengan asumsi nilai presisi $90 \%$ atau 0.1 dan populasi sebesar 176 siswa maka perhitungan untuk besaran sample dalam penelitian ini adalah sebagai berikut:

$$
\begin{aligned}
& n=\frac{176}{1+176(0.1)^{2}} \\
& n=\frac{176}{2,76} \\
& n=64
\end{aligned}
$$

(Dibulatkan menjadi 64 responden ) Sehingga total jumlah sampel yang digunakan adalah 64 responden. 


\section{Teknik Pengambilan Sampel}

Teknik pengambilan sampel yang digunakan dalam penelitian ini adalah Proporsional Sampling adalah: "pengambilan subyek dari setiap strata atau setiap wilayah yang ditentukan seimbang atau sebanding dengan banyaknya subyek dalam masingmasing strata atau wilayah."(Sutrisno Hadi;2007; 83). Proporsional sampling dalam penelitian ini dilakukan dengan mengambil prosentase (\%) sampel yang sama dari tiap kelas mahasiswa STIE AMM Mataram Semester Ganjil Tahun 2021/2022. Sampel masing-masing kelas yaitu Akuntansi B SMT $\mathrm{V}=14$ orang, Akuntansi A SMT VII sebanyak 17 orang, Akuntansi B SMT VII sebanyak 15 orang, dan Manajemen C SMT VII sebanyak 18 orang, dengan perhitungan sebagai berikut:

$$
\begin{array}{r}
\begin{array}{r}
\text { Akuntansi B SMT V }=\frac{40}{176} \times 64 \\
=14 \text { orang }
\end{array} \\
\begin{array}{r}
\text { Akuntansi A SMT VII }=\frac{46}{176} \times 64 \\
=17 \text { orang }
\end{array} \\
\text { Akuntansi B SMT VII }=\frac{42}{176} \times 64 \\
=15 \text { oramg } \\
\text { Manajemen C SMT VII }=\frac{50}{176} \times 64 \\
=18 \text { orang }
\end{array}
$$

Sehingga total keseluruhan sampel sebanyak 64 orang (responden)

\section{Teknik Analisis Data}

\section{Uji Validitas}

Suatu kuesioner dikatakan valid jika pertanyaan pada kuesioner mampu untuk mengungkapkan sesuatu yang akan diukur oleh kuesioner tersebut. Menurut Sugiyono (2006:240), bila nilai $r_{\text {hitung }}$ lebih besar dari nilai $\mathrm{r}_{\text {kritis }}$ ( $\mathrm{r}_{\text {hitung }}>0,30$ ) maka instrumen dikatakan valid, dan jika sebaliknya dikatakan tidak valid

\section{Uji Reliabilitas}

Uji reliabilitas adalah tingkat kestabilan suatu alat pengukur dalam mengukur suatu gejala/kejadian. Semakin tinggi reliabilitas suatu alat pengukur, semakin stabil pula alat pengukur tersebut. (Ghozali, 2006:40) Uji reliabilitas pada penelitian ini dengan menggunakan uji statisitik Cronbach Alpha ( $\alpha$ ) dengan menggunakan alat bantu program komputer SPSS. Suatu konstruk atau variabel dikatakan reliabel jika memberikan nilai Cronbach Alpha lebih besar dari 0,60 (Ghozali, 2006:41).

\section{Analisis Regresi Linear Berganda}

Dalam penelitian ini digunakan analisis regresi linear berganda untuk memecahkan permasalahan penelitian. Analisis regresi linear berganda digunakan untuk menganalisis pengaruh variabel independen terhadap variabel dependen. Persamaan dengan formula sebagai berikut:

$$
\begin{aligned}
Y=a+b 1 X 1 & +b 2 X 2+b 3 X 3+b 4 X 4 \\
& +b 5 X 5+b 6 X 6+b 7 X 7 \\
& +b 8 X 8+b 9 X 9+b 10 X 10 \\
& +b 1 X 11+. . e i
\end{aligned}
$$

Keterangan :

$\mathrm{Y}=$ Dekandensi Moral Dikalangan Mahasiswa

$\mathrm{a}=$ Intercep atau konstanta

$\mathrm{X} 1=$ Variabel Karakter Adab/Perilaku

$\mathrm{X} 2=$ Variabel Karakter Adil

X3 $=$ Variabel Karakter Amanah

X4 = Variabel Karakter Tanggung Jawab

$\mathrm{X} 5=$ Variabel Karakter Daya

Juang(Tangguh)

X6 = Variabel Karakter Disiplin

X7 $=$ Variabel Karakter Ikhlas

$\mathrm{X} 8=$ Variabel Karakter Inovatif

X9 $=$ Variabel Karakter Jujur

$\mathrm{X} 10=$ Variabel Karakter Kepedulian

X11 = Variabel Karakter Kepekaan

b1 = Koefisien regresi adab/perilaku

b2 $=$ Koefisien regresi adil

b3 = Koefisien regresi amanah

b4 = Koefisien regresi bertanggungjawab

b5 = Koefisien regresi daya juang(tangguh)

b6 $=$ Koefisien regresi disiplin

b7 $=$ Koefisien regresi ikhlas

b8 $=$ Koefisien regresi inovatif

b9 $=$ Koefisien regresi jujur

b10 $=$ Koefisien regresi kepedulian

b11 = Koefisien regresi kepekaan 
Vol. 10. No.1. Tahun 2022

ei $=$ Faktor lain diluar model

\section{Pengujian Hipotesis}

Uji Signifikansi Parameter Individual (Uji Statistik t)

Uji t pada dasarnya menunjukkan seberapa jauh pengaruh satu variabel independen secara individual dalam menerangkan variasi variabel dependen (Ghozali, 2006:84).

Uji Signifikansi Simultan (Uji Statistik F)

Uji signifikansi meliputi pengujian signifikansi persamaan regresi sejauh mana variabel bebas secara simultan (sama-sama) mempengaruhi variabel terikat. Uji keseluruhan dapat dilakukan dengan menggunakan statistik F .

\section{Koefisien Determinasi (R2)}

Koefisien determinasi (R2) pada intinya mengukur seberapa jauh

kemampuan model dalam menerangkan variasi variabel independen. Nilai koefisien determinasi adalah antara nol dan satu. Nilai R2 yang kecil berarti kemampuan variabel-variabel independen dalam menjelaskan variasi variabel dependen sangat terbatas. Nilai yang mendekati satu berarti variabelvariabel independen memberikan hampir semua informasi yang dibutuhkan untuk memprediksi variasi variabel dependen (Ghozali, 2006:83).

\section{HASIL PENELITIAN DAN \\ PEMBAHASAN}

Hasil Penelitian

Responden yang digunakan sebanyak 64 orang Mahasiswa Sekolah Tinggi Ilmu Ekonomi AMM. Responden tersebut dapat disajikan pada data Tabel berikut ini:

Tabel 4.1 Jenis Kelamin Responden

\begin{tabular}{clcc} 
No & Jenis Kelamin & Frekuensi & Prosentase $(\%)$ \\
\hline 1 & Perempuan & 52 & $81.25 \%$ \\
2 & Laki-laki & 12 & $18.75 \%$ \\
& Jumlah & 64 & $100 \%$ \\
\hline
\end{tabular}

Sumber : Lampiran 2

Responden yang mendominasi adalah berjenis kelamin perempuan sebanyak $52(81.25 \%)$

\section{Analisa Data}

Uji Validitas

Uji validitas digunakan untuk mengukur sah atau valid tidaknya suatu kuesioner.

Tabel 4.2 Hasil Uji Validitas

Variabel Corrected Item-Total R Kritis Keterangan Correlation

\begin{tabular}{lccc}
\hline Dekandensi & 0.421 & 0.3 & Valid \\
Adab(X1) & 0.527 & 0.3 & Valid \\
Adil(X2) & 0.608 & 0.3 & Valid \\
Amanah (X3) & 0.684 & 0.3 & Valid \\
Bertnggungjawab(X4) & 0.548 & 0.3 & Valid \\
Daya Juang(X5) & 0.406 & 0.3 & Valid \\
Disiplin (X6) & 0.381 & 0.3 & Valid \\
Ikhlas (X7) & 0.367 & 0.3 & Valid \\
Inovatif (X6) & 0.482 & 0.3 & Valid \\
Jujur (X9) & 0.458 & 0.3 & Valid \\
Kepedulian(X10) & 0.461 & 0.3 & Valid \\
Kepekaan (X11) & 0.421 & 0.3 & Valid \\
\hline
\end{tabular}

**. Correlation is significant at the 0.01 level (2-tailed).

Sumber : Lampiran 4 
Diketahui bahwa hasil pengujian validitas kuesioner penelitian secara keseluruhan dinyatakan valid, hal ini dapat ditunjukkan oleh nilai $r$ hitung lebih besar dari $r$ kritis atau ( $r$ hitung $>0.3$ ) (Sugiyono, 2006).

\section{Uji Reliabilitas}

Tabel 4.3. Hasil Uji Reliabilitas

\begin{tabular}{lccc}
\multicolumn{1}{c}{ Variabel } & Cronbach's Alpha & Standar & Keterangan \\
\hline Adab (X1) & 0.83 & 60 & Reliabel \\
Adil (X2) & 0.94 & 60 & Reliabel \\
Amanah (X3) & 0.98 & 60 & Reliabel \\
Bertanggung Jawab (X4) & 0.89 & 60 & Reliabel \\
Daya Juang (X5) & 0.64 & 60 & Reliabel \\
Disiplin (X6) & 0.89 & 60 & Reliabel \\
Ikhlas (X7) & 0.60 & 60 & Reliabel \\
Inovatif (X8) & 0.61 & 60 & Reliabel \\
Jujur (X9) & 0.65 & 60 & Reliabel \\
Peduli Thdp Msy.Lingkungan (X10) & 0.84 & 60 & Reliabel \\
Kepekaan (X11) & 0.67 & 60 & Reliabel \\
\hline
\end{tabular}

Sumber : Lampiran 5

Hasil uji reliabilitas yang ditunjukkan pada nilai Alpha seluruh variabel independen dinyatakan reliabel, karena memiliki nilai Alpha diatas atau lebih besar 0,6 $(\alpha>0,6)$, sehingga dapat digunakan untuk tahap selanjutnya.

\section{Analisis Regresi Linier Berganda}

Analisis Regresi linier berganda digunakan untuk mengetahui besarnya pengaruh variable independen terhadap variable dependen Hasil regresi ini dapat ditunjukkan pada Tabel 4.6 berikut ini:

Tabel 4.4 Hasil Koefien Regresi Linier Berganda

\begin{tabular}{|c|c|c|c|c|c|}
\hline Model & \multicolumn{2}{|c|}{$\begin{array}{l}\text { Unstandardized } \\
\text { Coefficients }\end{array}$} & $\begin{array}{l}\text { Standardized } \\
\text { Coefficients }\end{array}$ & $\mathrm{t}$ & Sig. \\
\hline (Constant) & 2.861 & .522 & & 5.478 & .000 \\
\hline $\operatorname{Adab}(\mathrm{X} 1)$ & .027 & .041 & .109 & .667 & .507 \\
\hline $\operatorname{Adil}(X 2)$ & -.087 & .082 & -.286 & -1.065 & .291 \\
\hline Amanah (X3) & .154 & .110 & .425 & 1.394 & .169 \\
\hline Bertnggungjawab(X4) & -.025 & .071 & -.065 & -.349 & .729 \\
\hline Daya Juang(X5) & -.092 & .085 & -.166 & -1.086 & .282 \\
\hline Disiplin (X6) & .445 & .124 & .517 & 3.590 & .001 \\
\hline Ikhlas (X7) & .216 & .139 & .256 & 1.557 & .125 \\
\hline Inovatif (X8) & .228 & .146 & .256 & 1.559 & .124 \\
\hline Jujur (X9) & .031 & .077 & .044 & .403 & .688 \\
\hline Kepedulian(X10) & .845 & .129 & .714 & 6.563 & .000 \\
\hline Kepekaan (X11) & 1.000 & .000 & 1.000 & 3.542 & .000 \\
\hline
\end{tabular}

a. Dependent Variable: Dekandensi

Sumber Lampiran 11

$$
\begin{gathered}
\mathrm{Y}=\mathrm{a}+\mathrm{b} 1 \mathrm{X} 1+\mathrm{b} 2 \mathrm{X} 2+\mathrm{b} 3 \mathrm{X} 3+\mathrm{b} 4 \mathrm{X} 4+\mathrm{b} 5 \mathrm{X} 5+\mathrm{b} 6 \mathrm{X} 6+\mathrm{b} 7 \mathrm{X} 7+\mathrm{b} 8 \mathrm{X} 8+\mathrm{b} 9 \mathrm{X} 9+\mathrm{b} 10 \mathrm{X} 10 \\
+\mathrm{b} 11 \mathrm{X} 11 \mathrm{e} \\
\mathrm{Y}=2.861+0.027+0.087+0.154+0.025+0.092+0.445+0.216+0.228+0.031 \\
+0.845+1.000
\end{gathered}
$$


Persamaan regresi tersebut dapat dijelaskan sabagai berikut:

Nilai konstanta $(\alpha)$ sebesar 2.861 artinya dekandensi moral dikalangan mahasiswa STIEAMM sebesar 2.861 satuan dengan asumsi variabel karakter adab/perilaku, karakter adil, karakter amanah, tanggung jawab, daya juang, disiplin, ikhlas, inovatif, jujur,kepedulian, dan kepekaan dalam keadaan konstan atau tetap, Nilai koefisien regresi variabel karakter perilaku sebesar 0,027 dengan probabilitas signifikansi sebesar 0.507 lebih besar dari $(>0,05)$. Hal ini membuktikan bahwa secara langsung akan meningkat sebesar $0,507 \%$, jika faktor karakter perilaku meningkat sebesar $1 \%$. Koefisien bernilai positif artinya terjadi hubungan searah antara karakter prilaku dengan dekandensi moral dikalangan Mahasiswa. Koefisien regresi variabel adil sebesar 0,087 dengan probabilitas signifikansi sebesar 0.291 lebih besar dari (> $0,05)$. Hal ini membuktikan bahwa karakter adil secara langsung akan meningkat sebesar 0,291\% jika faktor karakter adil meningkat sebesar $1 \%$. Koefisien bernilai positif artinya terjadi hubungan yang searah antara karakter adil dengan dekandensi moral dikalangan Mahasiswa. Selanjutnya variabel karakter amanah sebesar 0,154 dengan probabilitas signifikansi sebesar 0.169 lebih besar dari (> 0,05). Hal ini membuktikan bahwa secara langsung akan meningkat sebesar $0,154 \%$ jika faktor karakter amanah meningkat sebesar $1 \%$, dan koefisien bernilai positif artinya terjadi hubungan yang searah antara karakter amanah dengan dekandensi moral dikalangan Mahasiswa STIEAMM. Nilai koefisien regresi variabel karakter yang berhubungan dengan tanggung jawab sebesar 0,025 dengan probabilitas signifikansi sebesar 0.729 lebih besar dari $(>0,05)$. Hal ini membuktikan bahwa karakter yang berhubungan dengan tanggung jawab secara langsung akan meningkat sebesar 0,069\% jika faktor karakter tanggung jawab meningkat sebesar $1 \%$ dan positif artinya terjadi hubungan yang searah antara karakter tanggung jawab dengan dekandensi moral dikalangan Mahasiswa. Karakter yang berhubungan dengan daya juang bernilai sebesar 0,092 dengan probabilitas signifikansi sebesar 0.282 lebih besar dari (> 0,05). Hal ini membuktikan bahwa secara langsung akan meningkat sebesar 0,092\% jika faktor karakter daya juang meningkat sebesar $1 \%$ dan positif artinya terjadi hubungan yang searah antara karakter daya juang dengan dekandensi moral dikalangan Mahasiswa. Variabel disiplin nilainya sebesar 0.445 dengan probabilitas signifikansi sebesar 0.001 lebih kecil dari $(<$ $0,05)$. Nilainya positif berarti mempunyai hubungan searah antara disiplin dengan dekandensi moral dikalangan Mahasiswa. Karakter ikhlas nilainya sebesar 0.216 dengan probabilitas signifikansi sebesar 0.125 lebih besar dari (>0,05). Nilainya positif berarti mempunyai hubungan searah antara ikhlas dengan dekandensi moral dikalangan Mahasiswa. Variabel inovatif bernilai psitif berarti hubungan antara inovatif dengan dekandensi moral dikalangan Mahasiswa dengan nilai sebesar 0.228. Selanjutnya Variabel jujur dengan nilai sebesar 0.031 psitif berarti hubungan searah dengan dekandensi moral dikalangan Mahasiswa. Hal yang sama terjadi pada variable kepedulian yang bernilai positif sebesar 0.845 , sehingga dikatakan hubungan dengan dekandensi moral dikalangan mahasiswa searah. Kemudian Variabel karakter kepekaan dengan nilai sebesar 1.000 psitif berarti hubungan searah dengan dekandensi moral dikalangan Mahasiswa.

\section{Pengujian Hipotesis}

Uji Signifikansi Parameter Individual (Uji Statistik t)

Uji t pada dasarnya menunjukkan seberapa jauh pengaruh satu variabel independen secara individual dalam menerangkan variasi variabel dependen 
Hasil regresi ini dapat ditunjukkan pada Tabel di atas, dimana penjelasan antara lain.

Karakter adab/prilaku (X1) memiliki t hitung sebesar $0.667 \mathrm{t}$ tabel sebesar 1.674 dengan tingkat signifikansi dibawah 5\% yaitu 0,000. Hal ini memiliki makna bahwa secara parsial ada pengaruh yang signifikan antara variable Karakter prilaku (X1), terhadap dekandensi moral dikalangan mahasiswa. Karakter adil (X2) memiliki t hitung sebesar $1.065 \mathrm{t}$ tabel sebesar 1.674 dengan tingkat signifikansi diatas $5 \%$ yaitu 0,507 . Hal ini memiliki makna bahwa secara parsial ada pengaruh yang signifikan dan negative terhadap dekandensi moral dikalangan Mahasiswa. Selanjutnya Karakter Amanah (X3) dengan t hitung sebesar $1.394 \mathrm{t}$ tabel sebesar 1.674 dengan tingkat signifikansi diatas $5 \%$ yaitu 0,169 . Artinya secara parsial mempunyai pengaruh yang signifikan terhadap dekandensi moral dikalangan Mahasiswa. Demikian pula Karakter bertanggung jawab (X4) memiliki t hitung sebesar $0.349 \mathrm{t}$ tabel sebesar 1.674 berati ada pengaruh dan signifikan terhadap dekandensi moral dikalangan mahasiswa. Hal yang sama terjadi pada tujuh (7) karakter berikutnya yaitu karakter daya juang, disiplin, ikhlas, inovatif, jujur, kepedulian, dan kepekaan masing-masing mempunyai pengaruh dan signifikan terhadap karakter dekandensi moral dikalangan Mahasiswa.

\section{Uji Signifikansi Simultan (Uji Statistik F)}

Uji signifikansi meliputi pengujian signifikansi persamaan regresi sejauh mana variabel bebas secara simultan mempengaruhi variabel terikat. Uji keseluruhan dapat dilakukan dengan menggunakan statistik F. Hasil uji dapat ditunjukkan pada Tabel berikut:

Tabel 4.5 Uji Signifikansi Simultan (Uji Statistik F)

\begin{tabular}{|c|c|c|c|c|c|c|}
\hline \multicolumn{7}{|c|}{ ANOVA $^{b}$} \\
\hline Model & & Sum of Squares & $\mathrm{df}$ & Mean Square & $\mathrm{F}$ & Sig. \\
\hline \multirow[t]{3}{*}{1} & Regression & 1.271 & 2 & .635 & 37.204 & $.000^{\mathrm{a}}$ \\
\hline & Residual & 1.042 & 61 & .017 & & \\
\hline & Total & 2.313 & 63 & & & \\
\hline
\end{tabular}

Sumber data: :lampiran 11

Nilai F hitung sebesar 37.204 dan signifikansi 0,000. dikatakan bahwa $\mathrm{F}$ hitung lebih besar dari F tabel $(37.204>2.39)$ Jadi dapat disimpulkan bahwa terdapat pengaruh yang signifikan secara simultan (bersamasama) antara adab/perilaku, adil, amanah, bertanggung jawab, daya juang, disiplin,ikhlas, inovatif, jujur, kepedulian, dan kepekaan terhadap dekandensi moral dikalangan mahasiswa.

\section{Koefisien Determinasi (R2)}

Koefisien determinasi (R2) pada intinya mengukur seberapa jauh kemampuan model dalam menerangkan variasi variabel independen. Nilai koefisien determinasi adalah antara nol dan satu. Nilai R2 yang kecil berarti kemampuan variabel-variabel independen dalam menjelaskan variasi variabel dependen sangat terbatas. Nilai yang mendekati satu berarti variabel-variabel independen memberikan hampir semua informasi yang dibutuhkan untuk memprediksi variasi variabel dependen.Hasil uji dapat ditunjukkan pada Tabel dibawah ini.

Tabel 4.6 Uji Koefisien Determinasi ( R2 )

Model Summary ${ }^{b}$

Model R R Square Adjusted R Square Std. Error of the Estimate




\begin{tabular}{lrrrr}
\hline 1 & $.860^{\mathrm{a}}$ & .740 & .722 & .392 \\
\hline
\end{tabular}

Sumber data: :ampiran 11

Nilai R sebesar 0,860 berarti hubungan Korelasi cukup kuat. Adjusted $R$ Square $(\mathrm{R} 2)=0.722$ : Dekandensi moral dikalangan Mahasiswa dapat dijelaskan melalui variable adab/prilaku, adil, amanah, bertanggung jawab, daya juang, disiplin, ikhlas, inovatif, jujur,kepedulian, dan karakter kepekaan hanya sebesar $72.2 \%$. Sedangkan $27.8 \%(100 \%-72.2 \%)$ dapat dijelaskan melalui variebl-variabel lain yang tidak dimasukkan dalam penelitian ini.

\section{Pembahasan}

Dilihat dari respon atau tanggapan responden atas item-item pertanyaan yang ada pada lembar kuesioner penelitian, dapat diketahui bahwa masing-masing variable dengan indicator. Dalam penelitian ini, peneliti menggunakan alat analisa Regresi Berganda, namun dalam proses analisisnya peneliti menggunakan bantuan SPSS 20.0 For windows.

Untuk mengukur variabel dekandensi moral dikalangan mahasiswa (Y) digunakan 11 item, yang terdiri dari variabel karakter perilaku, adil, amanah, bertanggung jawab, , daya juang, disiplin, ikhlas, inovatif, jujur, kepedulian dan kepekaan. Dari hasil penelitian membuktikan bahwa secara simultan semua variabel berpengaruh signifikan terhadap dekandensi moral dikalangan mahasiswa (Y), hal ini dibuktikan dengan hasil perhitungan regresi yang dilihat dari nilai $\mathrm{F}$ hitung sebesar 37.204 dengan taraf signifikansi 0,000.

Sedangkan secara parsial variabel perilaku, amanah, disiplin, ikhlas, inovatif, jujur, kepedulian, dan kepekaan berpengaruh signifikan dan positif terhadap dekandensi moral dikalangan mahasiswa. Sedangkan karakter adil, bertanggung jawab, dan daya juang berpengaruh signifikan dan negative terhadap dekandensi moral dikalangan mahasiswa.. Dilihat dari nilai R2 Adjusted $R$ Square, $72.2 \%$ Dekandensi moral dipengaruhi oleh sebelas (11) variable, sedangkan sisanya sebesar $27.8 \%$ dipengaruhi oleh faktor lain yang tidak dimasukkan dalam penelitian ini seperti tempat, pelayanan administrasi kampus, pembinaan Dosen dan sebagainya.

Berdasarkan kesebelas variabel independen yang diuji secara individual yang paling dominan dalam mempengaruhi dekandendi moral adalah karakter kepedulian, hal ini karena nilai-nilai kepedulian yang diberikan oleh STIEAMM secara umum dapat memenuhi harapan mahasiswa baik dari segi bukti yang sudah tertanan pada masing-masing mahasiswa, daya tanggap terhadap pmberian nilai-nilai kepedulian, ikhlas dan inovatif.

\section{SIMPULAN}

\section{Simpulan}

Berdasarkan pemaparan latar belakang, permaslahan dan hasil analisa diatas, maka peneliti mengambil kesimpulan sebagai berikut:

Nilai konstanta $(\alpha)$ sebesar 2.861 artinya dekandensi moral dikalangan mahasiswa STIEAMM sebesar 2.861 satuan dengan asumsi variabel karakter adab/perilaku, karakter adil, karakter amanah, tanggung jawab, daya juang, disiplin, ikhlas, inovatif, jujur,kepedulian, dan kepekaan dalam keadaan konstan atau tetap, Dilihat dari sebelas (11) variable rata-rata mempunyai probabilitas signifikansi yang lebih besar dari $(>0.05)$, hal ini membuktikan bahwa terjadi hubungan yang serah variable independen dengan dependen.

Secara individual karakter prilaku, adil, amanah, bertanggung jawab, daya juang, disiplin, ikhlas, inovatif, jujur, kepedulian , dan kepekaan masing-masing mempunyai pengaruh dan signifikan terhadap dekandensi moral mahasiswa. Sedangkan dilihat secara simultan atau bersama-sama dimana nilai $\mathrm{F}$ hitung sebesar 
37.204 dan signifikansi 0,000. dikatakan bahwa $\mathrm{F}$ hitung lebih besar dari $\mathrm{F}$ tabel (37.204 > 2.39) Hal ini dapat disimpulkan bahwa terdapat pengaruh yang signifikan secara simultan (bersama-sama) antara adab/perilaku, adil, amanah, bertanggung jawab, daya juang, disiplin,ikhlas, inovatif, jujur, kepedulian, dan kepekaan terhadap dekandensi moral dikalangan mahasiswa.

Kemudian apabila dikaitkan dengan kuat atau lemahnya hubungan variable independen dan dependen maka sebagaimana yang dihasilkan koefisien determinasi dengan nilai $\mathrm{R}$ sebesar 0.860 berarti hubungan Korelasi cukup kuat Adjusted $R$ Square $(\mathrm{R} 2)=0.722:$ Dekandensi moral dikalangan Mahasiswa dapat dijelaskan melalui variable adab/prilaku, adil, amanah, bertanggung jawab, daya juang, disiplin, ikhlas, inovatif, jujur,kepedulian, dan karakter kepekaan hanya sebesar $72.2 \%$. Sedangkan $27.8 \%(100 \%$ - $72.2 \%)$ dapat dijelaskan melalui variebl-variabel lain yang tidak dimasukkan dalam penelitian ini.

\section{Saran}

1. Bagi STIEAMM, hasil penelitian menunjukkan secara umum pembinaan karakter yang berhubhungan dengan Adab/prilaku, adil, amanah, bertanggung jawab, daya juang, disiplin, ikhlas, inovatif, jujur, kepedulian, dan kepekaan, dalam membembentuk dekandensi moral dikalangan mahasiswa sudah cukup baik, sehingga perlu dipertahankan.

2. Bagi peneliti selanjutnya, metode yang digunakan masih jauh dari harapan peneliti, sehingga masih perlu diperkaya lagi dan juga alat analisa perlu ditingkatkan, variabel independen yang digunakan perlu disempurnakan, dan kajian tentang variabel-variabel independen lain di luar model penelitian ini yang berkaitan dengan pendidikan karakter dikalangan Mahasiswa.

\section{DAFTAR PUSTAKA}

A, Doni Koesoema. Pendidikan Karakter; Strategi Mendidik Anak di Zaman Global. Jakarta:PT. Grasindo. 2007.

Arikunto Suharsimi. Prosedur Penelitian Suatu Pendekatan Praktik. Jakarta: PT Rineka Cipta. 2010.

Asmani, Jamal Ma'mur. Buku Panduan Internalisasi Pendidikan Karakter di Sekolah. Yogyakarta: Diva Press. 2011.

Aunillah, Nurla Isna. Panduan Menerapkan Pendidikan Karakter di Sekolah. Yogyakarta : Diva Press. 2011.

Aqib, Zainal. Pendidikan karakter Membangun Perilaku Anak Bangsa. Bandung : Yrama Widya. 2011.

Azzet, Akhmad Muhaimin. Urgensi Pendidikan Karakter di Indonesia. Yogyakarta : Arruz Media. 2011.

Kusuma, Dharma, dkk. Pendidikan Karakter, Kajian Teori dan Praktek Di Sekolah. Bandung: PT Remaja Rosda Karya. 19.

Kemendiknas. 2010. Panduan Pendidikan Karakter. Jakarta: Pusat Kurikulum dan Kebukuan Kemendiknas

Kemendiknas. 2011. Panduan Pendidikan Karakter. Jakarta: Pusat Kurikulum dan Kebukuan Kemendiknas

Pusat Kurikulum Depdiknas. 2010. Bahan Pelatihan Penguatan Metodologi Pembelajaran Berdasarkan Nilai-nilai Budaya untuk Membentuk Daya Saing dan Karakter Bangsa. Jakarta: Kemendiknas

Pusat Bahasa Depdiknas. 2008. Kamus Bahasa Indonesia. Jakarta: Departemen Pendidi-kan Nasional 
Syukri, 2009. Peran Pendidikan di Perguruan Tinggi terhadap Perubahan Perilaku Kaum Intelektual (sosial-Individu). Jurnal Ilmiah Kreatif. vol 6 no 1, hal $1-15$.

Soetanto, Hendrawan. 2012. Pendidikan Karakter. Malang: Univ. Brawijaya

Sugioyono. Metodologi Penelitian Pendidikan ; Pendekatan kuantitatif, kualitatif, dan R\&D. Bandung: Alfabeta. 2008.

S, Margono. Metodologi Penelitian Pendidikan. Jakarta: Rineka Cipta. 2005.

UU No.20 Tahun 2003, tentang Sistem Pendidikan Nasional

Wibowo,Agus. Pendidikan Karakter; Strategi Membangun karakter Bangsa Berperadaban. Yogyakarta: Pustaka Pelajar. 2012.

https://www.google.com/search?safe=strict\& ei=03EpXILUIs_drQGu5pKoBA\&q $=18+$ pendidikan+karakter+menurut+ kemendiknas + pdf\&oq=download + bu ku+pendidikan+karakter+filetype $\% 3$ Apdf\&gs_l=psyab.1.2.0i7118.0.0..63495 ..0.0..0.0.0... ....0......gws-wiz.GYZZAIcjGn8 (Di Akses Pada, Tgl. 19, 26, dan 29 Marat 2021 )

https://www.google.com/search?safe=strict\& ei=o3EpXILUIs_drQGu5pKoBA\&q $=18+$ pendidikan+karakter+menurut+ kemendiknas+pdf\&oq =download + bu ku+pendidikan+karakter+filetype $\% 3$
Apdf\&gs l=psyab.1.2.0i7118.0.0..63495 ..0.0.0.0.0.0... ....0.......gws-wiz.GYZZAIcjGn8 ( Di Akses, Pada Tanggal 18 April 2021 )

https://www.google.com/search?safe=strict\& ei=03EpXILUIs_drQGu5pKoBA\&q =18+pendidikan+karakter+menurut+ kemendiknas+pdf\&oq=download+bu ku+pendidikan+karakter+filetype $\% 3$ Apdf\&gs_l=psyab.1.2.0i7118.0.0.63495 ..0.0..0.0.0... ....0......gws-wiz.GYZZAIcjGn8 (( Di Akses, Pada Tanggal, $17 \mathrm{Mei}$ 2021 )

https://www.researchgate.net/publication/323 364661_Hakikat_Pendidikan_Karakt er/download (Di Akses Pada Tanggal, 19 Jumi 2021 )

https://www.google.com/search?safe=strict\& ei=o3EpXILUIs_drQGu5pKoBA\&q $=18+$ pendidikan + karakter+menurut + kemendiknas+pdf\&oq=download + bu ku+pendidikan+karakter+filetype\%3 Apdf\&gs_l=psyab.1.2.0i7118.0.0..63495 ..0.0.0.0.0.0... ....0......gws-wiz.GYZZAIcjGn8 ( DI AKSES Pada Tanggal , 5,15,17, dan 27 Agustus 2021 )

https://www.google.com/search?safe=strict\& ei=o3EpXILUIs_drQGu5pKoBA\&q $=18+$ pendidikan+karakter+menurut+ kemendiknas+pdf\&oq=download + bu ku+pendidikan+karakter+filetype $\% 3$ Apdf\&gs_l=psyab.1.2.0i7118.0.0..63495 ..0.0.0.0.0.0... ..........gws-wiz.GYZZAIcjGn8 (Di akses , Pada Tanggal, 5, 12, 19, dan $26 \quad$ September 2021 